\title{
The Birch as a Source of Raw Material during the Stone Age
}

\author{
By EMIL VogT \\ (Landesmuseum, Zürich)
}

$I^{\mathrm{T}}$

$T$ is hardly necessary to point out that birch was one of the common trees of the younger stone age and that its wood was much used for technical purposes. This must have been even more the case in mesolithic times and during the upper palaeolithic period, when during a certain period this tree dominated the landscape to such an extent that we can even speak of a Birch period.

The use of birch wood soon made men acquainted with its own special properties. If at present we are first able to demonstrate a knowledge of these for the neolithic and later stages, it is not to be doubted that this merely represented a continuation of a mesolithic accomplishment. There are two properties of birch which are particularly well exhibited by the pile-dwelling finds. The bark can be detached from the tree in thin layers, is extraordinarily easily worked and can be sewn like fine leather. But, secondly, it is possible to obtain a pitch from the bark, which after correct preparation makes a particularly useful glue. The pitch occurs especially in the bark and allows rolled up pieces of this to burn with a clear flame. These so-called birch-bark tapers, which even in modern times played an important part in illumination, are found not uncommonly in the Swiss pile-dwellings.

It is already possible to show that birch bark was used for a variety of different purposes. In the first place one may mention objects made entirely from birch bark. We know from several examples that small containers were made from it. A sewn fragment of one such has been known for a long while from the pile-dwelling GachnangNiederwil. ${ }^{1}$ A nearly complete box, containing fish-scales, was found at the pile-dwelling of Port (Kt. Bern). ${ }^{2}$ It is not to be doubted that vessels of birch-bark played a great part in daily life and more especially in that of the mesolithic period when pottery was absent. But this bark was also used for many other purposes. Great pieces, made from single strips placed together, were used as floor-coverings as in the moor-village of Riedschachen in Federseemoor, south Germany. ${ }^{3}$ It was also used as an insulating medium in fire-places and particularly in ovens. ${ }^{4}$ There is no doubt that further excavation would make possible many more observations of this character. The interpretation of small packets of birchbark, containing small pebbles, was long debated. They evidently belong exclusively to the Cortaillod culture and can most probably be explained as net-weights. ${ }^{5}$

1 'Beiträge zur Kulturgeschichte,' Festschrift $R$. Bosch. Aarau 1947, Taf. II, 2.

2 O. Tschumi, Die Ur-und frïgeschichtliche Fundstelle von Port im Amt Nidau (Kt. Bern). Biel 1940, Abb. I 7.

${ }^{3}$ H. Reinerth, Das Federseemoor als Siedlungsland des Vorzeitmenschen. Leipzig 1936, p. 101.

4 l.c., p. 94.

' 'Beiträge zur Kulturgeschichte,' l.c., p. 49. 
PLATE VI
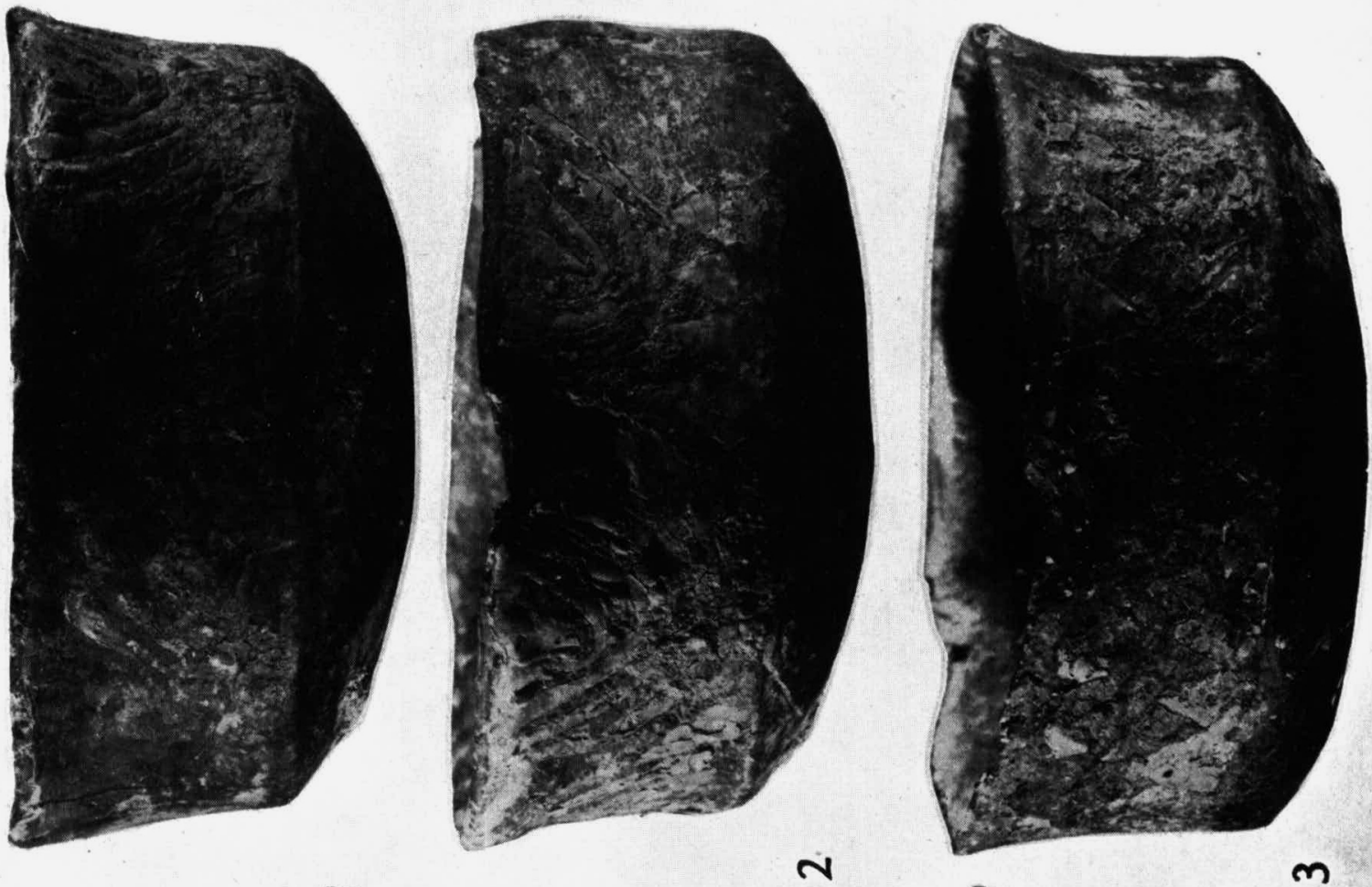

$\Phi$

岃

$\stackrel{5}{ \pm}$

$5 \frac{1}{0}$

造

.

I立

可

4.

욜

氙

\&

客芯

ن

要密

के द्ध

莺密

원

논

든

2...
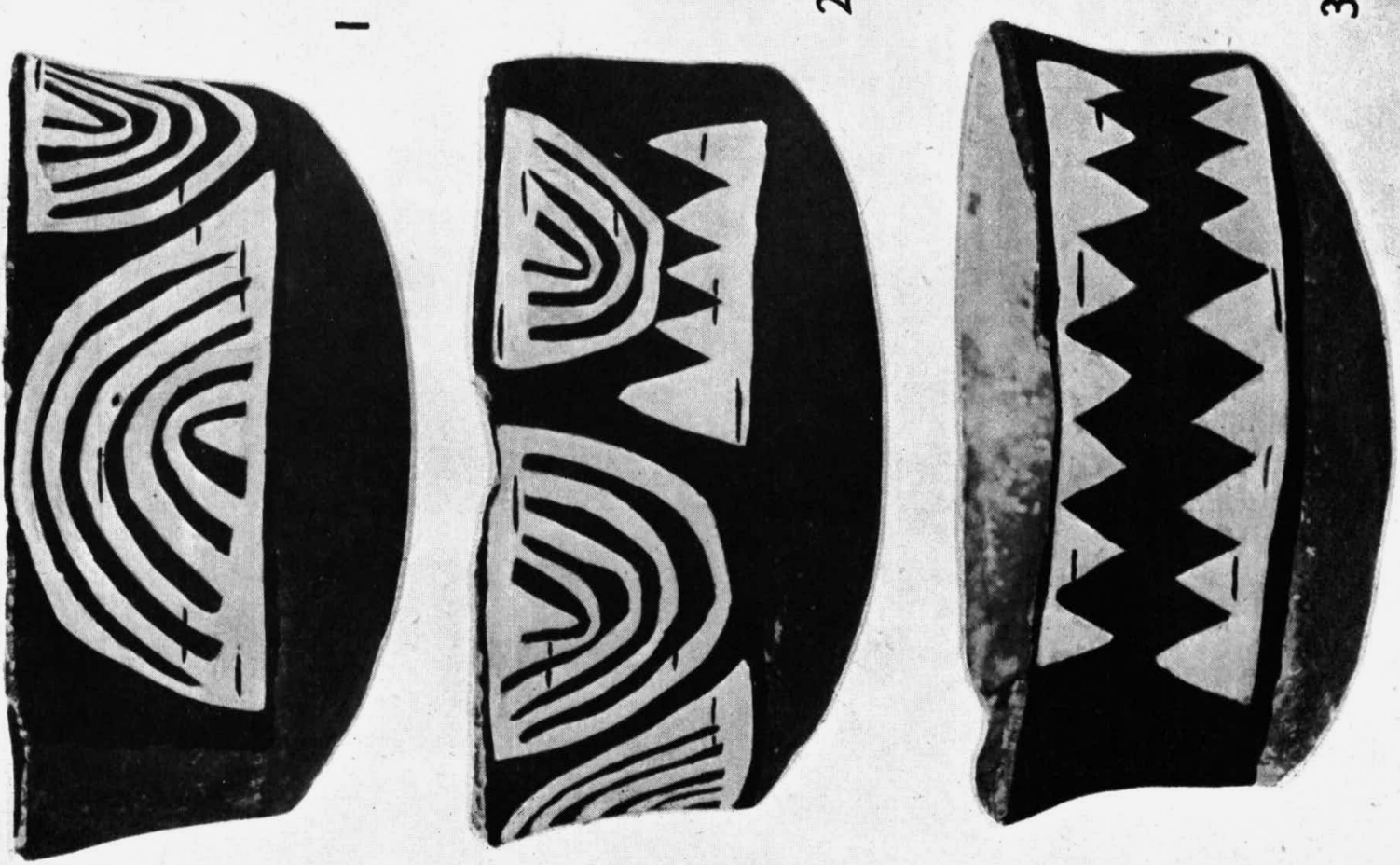

s

통

\pm -

吾

논

品

它踏

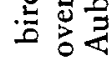

동ㅎㅀ

兘要

$\approx$ 红

믕

㐏急

它立

L

总壳

๖

4

: 
No. 5

PLATE VII

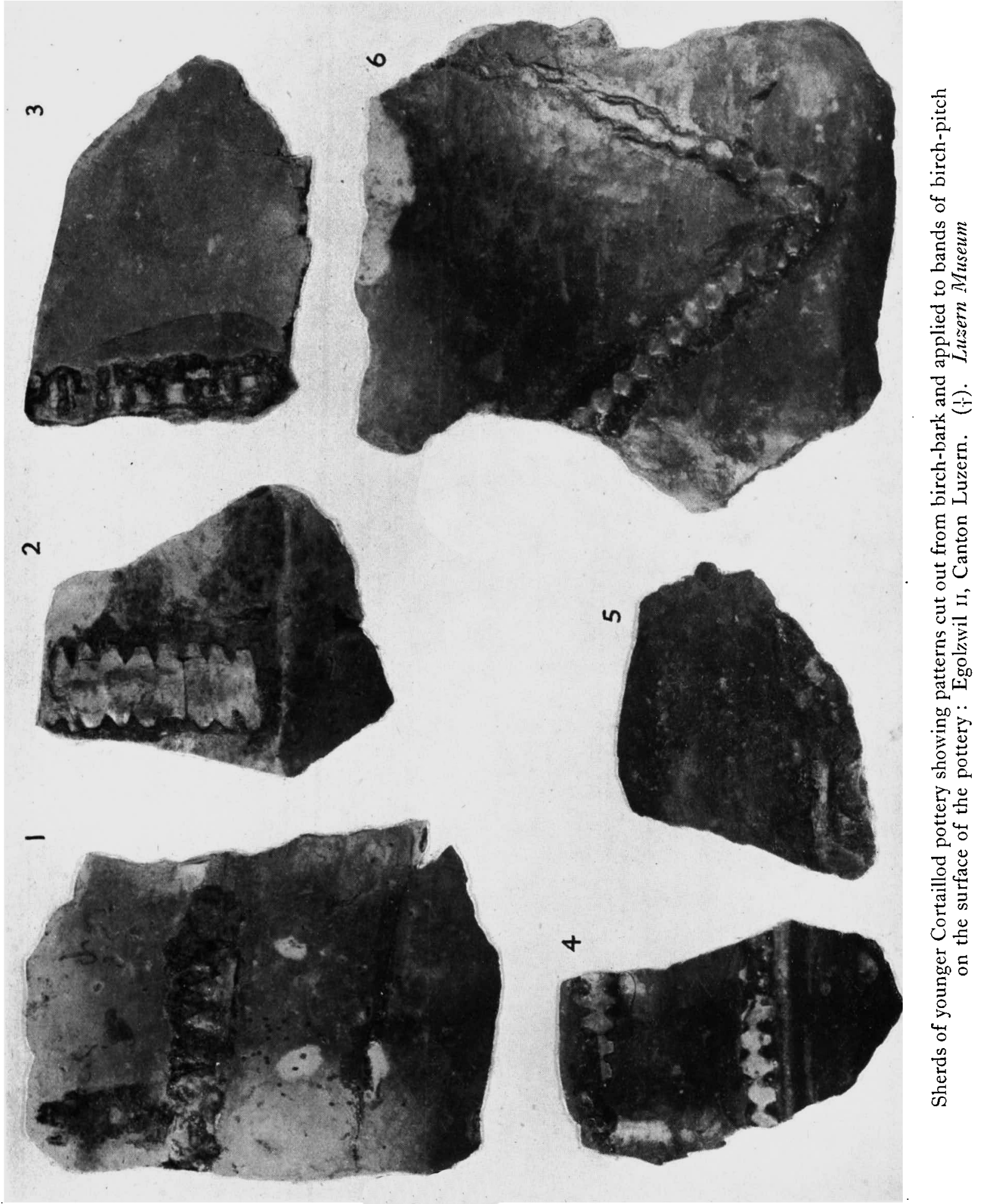




\section{Emil Vogt. The Birch as a Source of Raw Material during the Stone Age}

No less interesting are objects for which birch-bark has served as a constructional element or as a medium of decoration. From the pile-dwellings we know of three combs in which the grip is covered by birch bark. They belong to two types each of which are narrow and tall. Pointed pieces of wood are bound together at their upper ends with bast and the handle so formed stuck with pitch and overlaid with birch-bark. This protects the construction of the comb and at the same time gives a pleasing finish to the surface. These combs likewise belong to the Cortaillod culture.

Bark is met with in connection with pottery as a purely decorative feature (pls. vi and viI). Small cut-out patterns were stuck by means of birch-pitch to the outer surfaces of the darker coloured pot. Sometimes the more complex patterns appear to have been cut out after the bark had been stuck to the pot. An excellent example of this is provided by a small bowl, now in Neuchâtel museum, from the pile settlement of St. Aubin-Tivoli. The pattern can be reconstructed almost completely from the surviving traces. In her newly published dissertation $^{1}$ on the Cortaillod culture Fräulein V. von Gonzenbach has been able to show that the method of decorating pottery with birch-bark is typical only for the later stage of the culture. From this it spread to the contemporary Michelsberg culture of north Switzerland. Had these vessels not been found under such favourable conditions for preservation, we should today possess completely undecorated pots, which naturally would give a quite false picture of the culture. Particularly striking also is the style of the decoration, which can only with difficulty be compared with that found on pots with engraved patterns. The decoration on the pot from St. Aubin-Tivoli is especially characteristic. The groups of arc patterns may be compared with some on pottery from. Brittany and from England. ${ }^{2}$ Connections with these regions can also be found in the form of the pots concerned.

Even more original is the way in which the stone age people obtained pitch from birchbark. In the course of an excavation in the settlement of Lutzengütle near Eschen in the principality of Liechtenstein various objects were found which throw light on the method of producing the pitch, as well as some of the finished substance itself. Herr W. Kramer of the laboratory of the Swiss National Museum, is at present engaged upon further investigation of this problem and hopes to penetrate the secrets of the manufacture which was doubtless accomplished by very simple means. Birch-pitch had many different uses. It was used to fix flint blades in their handles, to secure arrowheads to their shafts and to mend broken pots, the cracks of which were sealed over by strips of birch-bark. We are now able to show that birch-pitch was still used as a sticking material for objects of the La Tène period. The original discovery of this must surely have been made by the hunters of the mesolithic or upper palaeolithic periods. Some such substance was absolutely necessary to fix the often very small worked flints characteristic of these people to their shafts. For the production of this essential material the birch provided an everrenewing source.

1 V. von Gonzenbach, Die Cortaillodkultur in der Schweiz. Birkhäuser, Basel, I 949.

' V. G. Childe, 'The continental affinities of British neolithic pottery,' Arch. $\mathcal{F}$., vol. 88 , p. 37 f., pls. IV-v. 